\title{
МУДРОСТЬ КАК ИНСТРУМЕНТ СОЗДАНИЯ НОВОГО МИРОВОГО ПОРЯДКА
}

\begin{abstract}
Каковы бросающиеся в глаза, характерные мировые тенденции последних лет?
\end{abstract}
Социальная эволюция превращает в рукотворные процессы многие ранее стихийно складывающиеся массовые явления. Решение политических проблем все в большей степени становится задачей граждан: человек превращается в субъект собственной истории. Давно уже метафора шахматной доски вошла в понятийный арсенал социальных наук. Разработаны и успешно применяются рефлексивные технологии управления странами и народами. Манипуляционный характер всех средств массовой информации, в том числе, интернета ни у кого не вызывает сомнений. В употреблении социальных ученых имеются такие понятия как сборка, наладка и разборка новых государств (со всем их правительственным аппаратом) и новых народов (с подложной биографией-легендой), регулярное районирование границ государств с их переделом при изменении обстоятельств, клонирование образов жизни и мышления, разработка нужных, часто искусственных систем ценностей, религий и формирование нужных мировоззрений, фабрикация любой версии истории и любой системы лже-образования, которая покажется уместной для поставленной задачи. Для того, чтобы эти версии не вошли в противоречие с реальной историей, тщательно уничтожается наследие древних цивилизаций, сравниваются с землей архитектурные, скульптурные и культовые памятники древнейших эпох, поджигаются и вывозятся в мусор великолепные академические библиотеки по всему миру. Известны и основные заказчики новейших геополитических конфигураций - мировые державы, крупные ТНК, надгосударственые и «подгосударственные» клановые образования. Но чего вы не найдете во всех этих «технизированных» преобразованиях, так это позитивного социального смысла, смысла служению духовной эволюции человека и общества или даже поддержания уникального статуса человечества во вселенной. Как будто поставлена задача коллективного самоубийства через деградацию и умопомешательство.

Как противостоять разгулу дегенерации, этой сатанинской революции прокаженных? Что говорит по этому поводу наука и как она может помочь нам отстоять духовные достижения?

Формирование мирового порядка давно уже стало рукотворным делом. Время от времени здесь происходят перемены, которые кардинальным образом сказываются на всех остальных аспектах общественной жизни, но, к сожалению, личная и общественная безопасность граждан отнюдь не растет. Все же, как и в других областях, развитие науки и ее достижения приводят к пересмотру сложившихся представлений.

Рассмотрим вкратце суть сложившегося мирового порядка. Он отличается крайней неустойчивостью, его нестабильность порождает ощущение падающей пирамиды, осколки которой разлетаются во все стороны, не оставляя неза- 
щищенными страны и народы; эти осколки всюду: они сеют хаос, анархию и возбуждают безотчетный ужас от их проникновения буквально в каждую семью, которая от страха и беспомощности запирается в себе, оставив одно окошечко в мир - интернет, но и то, по большей части, ради упреждения еще больших катаклизмов.

Это первое, психологически воспринятое впечатление сменяется, как в наводимой на резкость оптике, картиной ожесточенной борьбы интересов немногочисленных держав и оседлавших их клановых групп, вырвавшихся за пределы какого-либо контроля - общественного, государственного, цивилизационного. Единственно взаимно понятным языком, на котором они общаются между собой неведомыми широкой публике намеками, стал язык угроз, шантажа и международного терроризма.

Чем вызвана ожесточенность этой схватки клановых групп?

Главную роль в мировой пирамиде играет доминирующий субъект, берущий на себя роль окончательного арбитра во всех международных коллизиях. В последние столетия на эту роль, которая традиционно отводилась имперским образованиям, стали претендовать и крупные ТНК, отдельные финансово-промышленные группы, частные кланы и даже отдельные личности. Именно последние две разновидности доминирующих субъектов активно включились в формирование нового мирового порядка, который называют процессом глобализации. Ведущаяся ими в течение последних столетий политика скрытого лоббирования своих интересов через правительства и монархии европейских государств, Османской и Российской империй, а далее Советского союза и нынешней России, пришла в жесткое столкновение с закономерностями функционирования традиционных со- циально-политических образований, имеющих свои геополитические и общественные интересы. Возникла новая политическая линия, расходящаяся с интересами самих стран. Интересы безопасности этих стран вынуждают их к самостоятельной политике триангуляции международных взаимоотношений, которая идет вразрез с конфигурациями, построенными тайными или явными лоббистскими клановыми манипуляциями с опорой на подкупленную элиту этих стран.

В чем более конкретно состоит это противоречие?

Рассмотрим сначала процедуру триангуляции. Она состоит (по Манвелу Саркисяну в том, (geum.ru) что каждая страна старается максимально противодействовать наиболее грозному конкуренту, выстраивая цепь защитных государств, с одними из которых она входит в альянсы, а другие старается направить против угрожающего конкурента. В триангуляции участвуют три агента. Первый - это страна, надгосударственный, или «подгосударственный» субъект, доминирующий в регионе лидер, который в целях своей защиты инициирует триангуляцию. В настоящее время - это частный клан; второй агент - это страна или группа стран, служащих инструментами блокировки, нейтрализации или даже ликвидации соперника и конкурента инициатора триангуляции. Третья сторона или агент - это мишень или жертва триангуляции, вызывающая беспокойство или угрожающая доминирующему субъекту или конкурирующая с ним в каком-то аспекте. Сегодня такой третьей стороной стала сама конструкция государства. Т. е., стандартная тройка такова: активный субъект (заказчик) - инструмент-ликвидатор - жертва. Заказчик активно поддерживает ликвидатора всеми уместными материальными ресурсами и нужным вооружением и создает через СМИ иллюзорную картину, якобы, антагонистических противоречий между ликвидатором и жертвой, 
неразрешимых никаким иным путем кроме как военным. При этом сам заказчик, как принято, остается в тени. О нем никто ничего плохого не скажет.

Специфика современного состояния в том, что ведется глобальная война против всех духовных ценностей человечества, а особенно против всех государств как формы существования народов. Завоевание мирового господства, которым одержим доминирующий клан, должно быть одним единым процессом, поэтому разрозненные, казалось бы, события мировой политики на самом деле пронизаны одной стратегией и руководятся из одного центра. Поэтому это не просто война, а мета-война: война, состоящая из многих или даже всех войн.

Но невозможно вести войну со всеми сразу и объективно возникает проблема удобной фальсификации: чтобы все страны не объединились против агрессора, объявляется война одному официальному объекту, но лишь для того, чтобы под прикрытием этой «войны» наносить поражение другим фактическим объектам - государствам как главным помехам мирового господства. Особенно удобен виртуальный блуждающий фантом - международный терроризм, который при необходимости можно сфокусировать в любую нужную точку мира, чтобы под предлогом борьбы с ним уничтожить очередное государство. Хотя до сих пор никаких доказательств существования таких сил террористов, против которых надо было бы развертывать комплексы ПВО и войсковые части мировому сообществу не известно. Однако развертывание выполняет морально-психологическую задачу «накачки» населения психозом страха и необходимости войны, ее легитимизацию, заодно и доводя контроль «за мозгами» до унизительного осматривания нижнего белья, например, в аэропортах.

Причем, предварительно развязывается компания по дискредитации юридической ле- гитимности государственного суверенитета, например, из-за злоупотребления властью, коррупции, нарушения прав человека, недемократичности режима и т. д. Нелегитимность суверенитета делает государственные границы прозрачными для меты-войны, открывает страну для агрессии. Чтобы сделать агрессию приемлемой для мирового сообщества и замаскировать подмену ценностей, создаются лже-ценности - демократия, права человека, гендерное равенство и др. Это антиподы общепризнанных духовных ценностей. Причем, как правило, ценностью становится то, что соответствует выгоде агрессора. А злом определяется все то, что противоречит стратегии порабощения мира агрессором. Т. е., происходит не просто маскировка «зла», а превращение его в "добро», чтобы уже как "добро» оно встречало не противодействие, а помощь и одобрение мировой общественности, питаемой вывернутой наизнанку агрессором системой ценностей.

Посредством подобной легитимизации метавойна из средства достижения мирового господства превращается в, якобы, выражение коллективной воли мирового сообщества, в наведение желаемого порядка. Тогда те, кто пытается противостоять агрессору, сами, в определенной мере, становятся нелегитимными. Мета-война основана на фальсификации ценностей, перевертывании представлений о добре и зле, когда мощной информационно-психологической обработкой создается обратное отношение в ним. Снова подтверждается старая истина, что «сатана всегда принимает вид ангела, а его служители - вид служителей правды».

Любой мировой порядок подразумевает законность и порядок, иначе - анархия, хаос, при которых невозможно стабильное и надежное мировое господство. Следовательно, война трансформируется немедленно в полицейские операции по наведению и поддержанию нового мирового порядка, новой законности, основан- 
ной на подмененной, ложной системе духовных ценностей. Такова технология создания «глобальной номенклатуры», разрушающей национальные государства и приводящей к тотальному электронному контролю за людьми. Народы превращаются в массы, лишаются свободы воли, свободы совести и, вообще, права на жизнь.

Поскольку правила задает самый сильный субъект, то поневоле их принимают и все остальные страны (и не только они) по отношению к более слабым. Понятно, что более действенно это получается только у сильных и имеющих нужные ресурсы, но в итоге, каждое государство и каждый народ вынуждены враждовать не со своими естественными соперниками (если таковые вообще есть), а с тем государством или народом, которые являются угрожающими для заказчика, через навязываемую им систему ценностей. А заказчиком сегодня чаще выступает родственный клан или ТНК, включая финансовопромышленные группы. Если рассмотреть триангуляцию с самого высокого уровня, то этот клан начинает разрушать самое доминирующую державу. США как инструмент клана представляется миру как агрессор, на которого и вешаются все грехи. Клан, будучи враждебен, самим США, настраивает все страны против них, т.е., выносит враждебность вовне, провоцирует антиамериканизм, за которым как за ширмой и прячется клан, и превращает все остальные страны во врагов своих врагов, хотя бы даже, если они родственны по культуре и языкам. Обострившиеся отношения между США и Европой тому красноречивый пример.

Вообще, попутной задачей триангуляции является разрушение или ослабление каких-либо союзов между государствами и народами. Последовательно проведенная триангуляция приводит к полной атомарности как на мировой арене, так и в общественной жизни, поскольку к каждому субъекту надо подобрать враждебный, нейтрализующий его или вообще ликвидирую- щий его субъект (создать треугольник). Например, в эпоху господства Великобритании, все европейские народы находились в смертельной вражде друг с другом, а особенно ненавистен был Великобритании союз между Германией и Россией, почему они так часто воевали между собой к вящей выгоде "доброй, старой», «непричастной ни к чему» Англии. Еще раз правы китайцы, уже тысячи лет назад выработавшие иммунитет против этой триангуляции: «Сидеть на холме и наблюдать за схваткой тигров», или «Сидеть на пригорке и ждать, пока по реке проплывет труп твоего врага».

Триангуляция немедленно проникает и в бытовое сознание населения, обеспечивая эмоциональную поддержку масс неприглядной политике. В бытовой культуре народов политика триангуляции выдает себя постоянно резонирующими стереотипами о других: «фашистах-немцах», «макаронниках-итальянцах», «украх» и др. В любой европейской стране можно в закрытой частной беседе услышать обидные для других народов клички, что является симптомом еще актуальной политики триангуляции, неосознаваемой самим населением. В отличие от европейцев, русские не делают различий между доверительным общением и площадной речью и буквально уже рождаются под аккомпанемент ругательств в отношении «чурок» и других народов, оставаясь всю жизнь девственно чистыми и непугаными в отношении морали и уважения к другим. Естественно, они очень удивились бы, если бы узнали, что в рыночных отношениях за оскорбления других народов очень даже хорошо платят, и можно поправить свое материальное положение даже в условиях кризиса. И они совсем не подозревают, что являются бесплатными разносчиками скрытно проводимой изоляции России от всех ее союзников. В этом плане стоит отметить одно из ценных в психологии армян качество - неумение и нежелание ненавидеть другие народы. И пока- 
зательно, что в речи армян почти не мелькают обидные для других народов прозвища (за исключением неотмщенных еще турок). Инстинктивно, армяне понимают, что ненавидеть других - это бесплатно выполнять роль натравливаемого пса, причем, очень часто именно на своих потенциально духовно близких союзников.

Социологические исследования предпочтения народов и стран, регулярно выпоняемые в разных странах, наглядно презентируют эффективность и итоги, скрытно проводимой триангуляции. В этом плане, можно было бы подумать, как поднять статус Армении, например, в России. И здесь нет мелочей. Часто употребляемое в экономической сфере сокращение АРМ - автоматическое рабочее место - должно быть в судебном порядке закреплено за армянскими фирмами и предприятиями по всему миру, должно быть частицей их бренда, как слово шампань соотносится с французским происхождением. Арм-газ явно указывает на страну и отличается от Рос-газа, на который армяне не претендуют. А если все же надо сокращенно воспроизвести автоматическое рабочее место, то более прозрачным будет, например, АвРаМ.

Таким образом, вековые действия упоминаемых кланов по тайному лоббированию своих частных интересов в русле триангуляции взаимоотношений приводят к построению вполне определенной мировой конфигурации с ясно очерченными и угрожающе демонстрируемыми свою силу "уважаемыми членами» и остальными, стоящими на коленях изгоями. Ввиду доминирования прежде всего частного интереса, эта конструкция неустойчива, поэтому она должна сопровождаться постоянным противопоставлением друг другу всех элементов конструкции, нуськиванием их друг на друга, огульной маргинализацией конкурентных сообществ, приписыванием им всевозможных отрицательных ка- честв и ярлыков. Для выполнения этой роли, нужно, прежде всего, приватизировать и овладеть всеми СМИ, поставив их под централизованный контроль. Опять же, ввиду не только частного, но и становящегося антиобщественным характера многих выполняемых в русле этой триангуляции операций, в конечном счете, смысл всей мировой конструкции международного порядка вырождается в структуру, чья цель заключается в устранении свидетелей собственного преступления. Как говорится, с чего начал, к тому же и придешь.

Однако, устранение свидетелей преступления - это уже новое преступление, и у него тоже найдутся свидетели. И так без конца. Или вернее до торжества справедливого и трагического для инициаторов такой триангуляции конца.

Но международная общественная жизнь идет по своим каналам, и неуклонно растет пропасть между внедренным в мировой порядок паразитирующим частным интересом и принципиально общественным характером всей человеческой жизни, а особенно духом традиционных государств, ставящих частные интересы ниже общественных. Соответственно, разнятся выстраиваемые ими по правилам той же триангуляции иерархии, но включающие уже новые, более общественно значимые и на основе иных ценностей геополитические конфигурации, иногда кардинально отличающиеся от текущего мирового порядка.

Мысль о том, что на процессы триангуляции можно влиять рукотворным образом, появилась в европейском сознании не так давно. Иначе не было бы столь безжалостных войн по изменению мирового порядка с помощью последовательно и эффективно проведенных революций: как, например, в Англии в 1688 г., во Франции в 1789 г., в Германии в 1848 и 1918 гг., в Турции в 1909 г., в России в 1917 г. и далее в постсоветских и арабских странах уже в наше время. Если бы европейская мысль вычленила 
бы этот скрытный алгоритм возбуждения масс ранее (или познакомилась бы с китайским решением этого вопроса), то эти алгоритмы не были бы столь разрушительны, пробились бы иные конфигурации мирового порядка.

Приведем пример столетней давности, содержащий и потенциально иную, не столь трагическую и безысходную для армян конфигурацию. В том, что она не состоялась, виновны многие обстоятельства, но наиболее важное из них - отсутствие элиты и политической грамотности лидеров страны-жертвы. В период Геноцида армян турецкую партию «Единение и прогресс» (инициатора этой трагедии) и турецкое правительство того времени поддерживала и вооружала Германия. Но слово «Германия» есть иное обозначение слова «Армения», слово «Herman» есть немецкое самоназвание армян, военные гарнизоны которых еще во времена римской империи составили костяк германского народа. Но чтобы сами немцы были далеки от осознания культурной и генетической близости армян и немцев, рейхсканцлером Германии того времени путем тайного лоббирования был назначен представитель клана Ротшильдов Бетман-Гольвег, Теобальд (1856-1921), сыгравший немалую роль в развязывании первой мировой войны. Он происходил из известной банкирской семьи, окончил Гарвардский университет и входил в клан Ротшильдов. Ну, а «неравнодушное» отношение этого клана к армянам хорошо известно.

Пронизанные тревогой и чувством сострадания к армянам донесения германских послов и консулов, работавших в Турции в то время, как об этом свидетельствует книга Вольфганга Густа Геноцид армян. (Вольфганг 2005: 675) разбивались о жестокосердную логику этого рейхсканцлера, пропитанную жаждой разрушения России и, естественно, в первую очередь, уничтожения ее союзников - армян. В своих увещеваниях германским послам, озабоченным чудовищным истреблением армянского населения, этот изверг напирал на то, что интересы Германии превыше всего, а они требуют поддержки Турции.

Но в то же время известно, что иная, альтернативная концепция внешнеполитической стратегии Германии того периода исходила из того, что не Россия, а владычица морей Британия стоит на пути германского развития. В интересах же Германии было бы допустить выход России в Средиземное море, поскольку это неизбежно приведет ее к конфликту с Британией. В том же духе в сентябре 1914 г. представитель промышленной группировки Тиссена М. Эрцбергер поставил перед правительством рейха задачу элиминирования «нетерпимой опеки» над Германией со стороны Британии в основных вопросах мировой политики. Вторая стратегическая линия Германии, сторонником которой была и вся военно-морская партия в целом, желала окончания войны и союза с Россией и выступала за помощь антианглийским элементам в Индии, Египте и др. регионах (см. :http://wordweb.ru/ wwone/10.htm.http://wordweb.ru/wwone/10.ht). Как испуганно писал известный своей англосаксонской ориентацией геополитик Ратенау в 1916 г., в письме Секту, германо-русское согласие «сделает все балканские страны, включая Турцию, зависящими от этих двух стран, даст им выход в Средиземноморье и заложит основание общей будущей политики в отношении Азии. Без русской помощи германская политическая активность и экспансия на Ближнем Востоке и на Балканах будет жалким и неудовлетворительным суррогатом. (см.:http://wordweb.ru/wwone/10.Ht m.http://wordweb.ru/wwone/10.htm). Т. е., при победе иной ориентации армяне оказались бы в союзной связке с Германией и Россией и, вполне возможно, избежали бы геноцида. Знали ли лидеры армян того периода об этой альтернативе и что предприняли для ее осуществления?

Другой пример, взаимоотношения России и Израиля. Несмотря на то, что Израиль давно от- 
крыто объявил себя врагом России как геополитической единицы, участвует во всех конфликтах на стороне врагов России, снабжает их своим оружием, инструкторами, подстрекает к антироссийским действиям, интересы клана Ротшильдов и их лоббистские усилия настолько сильны, что вынуждают Россию как страну предавать своих естественных культурных и геополитических союзников и просто исторических друзей.

В итоге, в мире возникают противоречивые политические установки, кровавым разрезом проходящие по телам многих стран, разделяющие их на две враждебно настроенные друг по отношению к другу группировки, готовые вступить в гражданскую войну. Сегодня на Украине вживую осуществляется вечный сценарий двойственной триангуляции, который в России именовался расколом между западниками и славянофилами.

Между разными триангуляциями есть важное различие. Одна исходит из паразитического, колониального освоения ресурсов попираемой частными кланами страны, другая - настроена на возобновление внутреннего развития своими силами и защиты своих ресурсов. Аналогично в Армении существуют две параллельные линии внешнеполитической ориентации. Одна, исходящая из интересов клана, настаивает на дружеских отношениях с Турцией, другая - исходящая из собственной безопасности, помнит уроки истории. Принципиально говоря, таких линий может быть много, и их количество зависит от числа конкурирующих за доминирование субъектов, каждый из которых проводит собственную трангуляцию, заново разделяя страны и народы на «друзей» и «врагов». За свою долгую историю Армения претерпела множество подобных триангуляций, оставивших свой след в народных симпатиях и антипатиях.

Как мы уже говорили, спецификой триангуляции, проводимой частными кланами является неустойчивость выстраиваемой иерархии. Поэтому у кланов нет иного средства ее поддержать, кроме как методом интенсивной дебилизации населения и подкупа элит всех стран, в которых им приходится создавать неестественную, перевернутую иерархию политических ценностей, а в крайнем случае - подтолкнуть лишаемые разума народы к развязыванию третьей мировой войны. Но там где гибель, там же и спасение. Есть и побочная линия у этих процессов триангуляции.

В атомарном разъединении народов само собой возникает потребность в культуре консолидации, в возникновении народа, который умело соединял бы разрозненные части и выигрывал бы от их синтеза в единый работающий социальный механизм. Это и есть византийская линия, которую кланы разрушили 500 лет назад, но ведущего субъекта которой уничтожить так и не смогли. «Объединяй и процветай» - вот лозунг, который армяне осуществляли на протяжении тысячелетий. Сегодня этот мудрый принцип должен стать руководством к действию народов, желающих иметь будущее.

Почему именно сегодня обострились противоречия между геополитическими иерархиями?

На мировую сцену выходит новый геополитический лидер. Уже нет того напряжения советско-американских полюсов, которое создавало бы идеологическую динамичность пустоты. Россия, примирившаяся со своей ролью арьергарда Европы, уже не может служить для нее пугалом - инструментом США ее нейтрализации (вспомним правило триангуляции). Будет выстраиваться новый расклад сил, происходить передел собственности, будет производиться новая триангуляция взаимоотношений между государствами. Будет создаваться новый гомоморфизм доминирующего лидера и всей мировой 
системы, включая правовую и организационную сторону. Гомоморфизм означает выстраивание нормативной части мировой системы в полном соответствии с интересами и выражающими их ценностями доминирующего субъекта. Bсе, что не удается поставить на службу этим интересам, будет безжалостно уничтожаться. Это понимают и кланы, дрейфуя в направлении усиливающегося лидера. Но пока наметилось междуцарствие - наиболее благоприятная пора для пробуждения национального самосознания слабых и униженных народов.

Вспоминаются старые обиды, звучат заслуженные и незаслуженные требования о перекройке границ, об автономии моноэтничных регионов, множатся взывания к справедливости в мировом масштабе, все более утончаются понятия и принципы международных взаимоотношений. И тут самая пора вспомнить еще об одном измерении человечества, которое пронизывает всю его историю.

Народы развиваются не равномерно, они имеют разный культурный возраст, находятся на разных стадиях общечеловеческого взросления. У одних народов в языке даже нет еще понятий, обозначающих моральные состояния, еще нет представлений о нравственности, о совести, о чести и благородстве, о великодушии и милосердии, о духовности, наконец. Но эти народы голосуют в ООН, решают судьбу народов, которым они иногда обязаны культурой и цивилизацией, но решают иногда на меркантильной основе, поскольку до другой они еще не доросли.

Но подобный, выстраиваемый с помощью финансов мировой порядок давно уже стал карикатурой на человеческое достоинство. Это все равно, что людоедам предложить классифицировать ученых по рангу. Они их выстроят по степени сытности.

Другим отягчающим обстоятельством, ускоряющим гибель нынешнего мирового порядка, является маргинализация интеллектуалов всех наций. Они отброшены на обочину, представлены как ненужный мусор, на который направлены бомжи и клошары всех стран, с помощью которых создаются политические партии-стада и назначаются безропотные начальники и министры. Но закон противодействия невозможно отменить. Интеллектуалы стали формировать национал-патриотические объединения, более развитые интеллектуалы прибегли к международным альянсам прогрессивных сил, ими заполнились антиглобалистские движения, попутно возникают концепции нового «нового мирового порядка» и даже создаются мировые форумы мудрости.

Но больше всего беспокоит народы и государства нынешнее отсутствие безопасности. Марионеточные проституированные правительства не способны поддерживать устойчивость общественного порядка и продаются всем, кто больше заплатит. Они неподотчетны обществу. Их хозяева - в надгосударственном пространстве. $И$ они продают им недра, ресурсы, интеллект, здоровье детей и будущее страны. А кто же будет защищать народ? Вот так и возникают контр-движения в сторону той геополитической иерархии, которая обеспечит безопасность и сохранность народов. Но сменить марионеточные правительства невозможно в иное время. Слишком велики силы - иногда это несколько договорившихся между собой сверхдержав - которые заинтересованы в увековечивании этих, очень часто криминальных режимов. Поэтому только появление на горизонте нового геополитического лидера, не уступающего прежнему в мощи, может вдохнуть надежды на изменение положения.

Возникают новые связки между государствами и блоками государств, идет прокладывание новых дипломатических и международных путей: Россия устанавливает сотрудничество с Китаем, но тут же в упреждающих целях сближается с Вьетнамом - смертельным врагом Ки- 
тая, и в тех же целях идет речь об установлении более близких отношений с Японией. Возникает новое пространство маневров и для Армении.

Близящийся отказ от финансово заданной пирамиды вывел на передний план критерии и понятия международной солидарности, и неожиданно для некоторых стран, в частности, для Армении, сделал ее востребованной в поисках понимания иных оснований установления мирового порядка. Фактически, произошло обращение к сверхмягкой силе духовных измерений человечества, призванных уравновесить зловещую роль финансов.

Но не иллюзорны ли надежды на изменение статусов? Как будет выглядеть мировой социальный порядок, если доминирующим субъектом станет Китай? Как будут перестраиваться институты в подневольных (во всех остальных) странах? Останется ли институт прав человека, ювенальная юстиция, сохранится ли образование в болонском ошейнике, какие предметы будут изучаться в школах и вузах, какие сферы производства будут разрешены, а какие - подавлены, как будет выглядеть космическое противоборство, какие этнические группы будут возвышены, а какие - принижены, по каким критериям будет набираться колониальная администрация во всех странах, из уголовников, как сегодня, или иначе, продолжится ли чипизация населения, ведущая к информационным концлагерям и т. д. и т. п.?

Самый простой ответ: будет выстроена мета-структура, использующая все построенное ранее в своих целях. Конечно, точек напряжения будет немало, но главное, что может нас интересовать в этом вопросе: какую стратегию предпримет Китай? Возьмет ли он на вооружение западный принцип: «Уничтожь своего соседа, ради своего блага», или склонится к более мудрому принципу: «Помоги преуспеть твоему соседу, ради своего же блага». От политики «помоги преуспеть твоему соседу» выигрывают все
- это начало развертывания нового социального субъекта, поддерживающего чистую социальность как таковую, в то время как от менталитета «разори твоего соседа» выигрывает лишь одна сторона, как правило, характеризующаяся антисоциальной установкой. Этот, доминирующий в XX-XXI веках криминальный менталитет, можно в целом определить термином: «игра с нулевой суммой». Вы выигрываете, если другие проигрывают, вы преуспеваете за счет того, что другой нищает.

Как можно малым странам влиять на конфигурацию мирового порядка?

В числе тех факторов, которые сулят более внимательный учет интересов и слабых стран, тщательное изучение индивидуальных психологий народов и государств, прослеживание траекторий их истории, принимаемые типичные решения в типичных обстоятельствах, стандартные развязки бифуркаций в циклических и исторически повторяющихся ситуациях, пределы их ментального роста и высота их духовности и т. д. и т. п. Возвышение точки зрения до птичьего полета (можно и выше) неизбежно приведет к тому взгляду, с которого они предстанут как выстроенные историей социальные машины, ведущие себя достаточно предвидимым образом. Именно на этом качестве основан экспертный прогноз даже в отношении строго засекреченных политических проектов и линий поведения разных стран и, вытекающие из прогноза, упреждающие адекватные действия. Любой шахматист, предвидящий заранее ходы соперника, согласится с этим тезисом. В конечном счете может быть построена соответствующая классификация народов и государств, в которой, надеюсь, найдут себе место и такие рубрики как преступные народы, государства или даже религии. Явно новая классификация будет выгодно 
отличаться от той, которая была объявлена при прошлой триангуляции.

С каждым новым ее витком вовлекается все большее число народов и государств, участвующих в ней не только на уровне инструментов или статистов, но и в качестве заказчиков, т.е. идет вполне эволюционное выравнивание уровня субъектной активности и политической развитости даже малых стран.

Поскольку знания сейчас быстро распространяются и быстро обновляются, уже это дает информационное преимущество малым странам ввиду их большей гибкости. Но если мы можем точно предсказывать следующие ходы триангуляций, отличать склонных к паразитизму субъектов, от общественно более значимых, то и выводимые из триангуляций пропагандистские клише - конъюнктурные установки к тем или иным странам, зомбирующие население стран, тоже в наших руках: мы их можем изменять по собственным соображениям.

Всем живым существам присуща экспансия, в результате которой всегда появляются новые конфликты и обостряются старые. В то же время это - рукотворные процессы, которыми можно управлять на уровне народных масс. Мы видели, что триангуляция не может обойтись без обработки масс в нужном русле. Между странами, предназначенными к закланию, насаждается ненависть и провоцируются стычки. Хотя уже на уровне народной дипломатии можно смягчать и обуздывать крайние проявления озлобленности, но можно подойти к этой задаче более серьезно. Для этого на факультетах социологии надо начать готовить социологов, политологов, компромиссологов, которые обучены работать с широкими народными массами в рамках антилиберальных, традиционных ценностей. Они могут притормаживать, там, где это требуется, рост негативизма в отношении других народов, или даже четко указывать на тех, кто является реальным выгодоприобретателем по- вышенной конфликтности. Если Сирия объявлена средоточием зла, то почему бы на всех интернетных перекрестках не усилить защиту ее моральных и культурных достоинств, грубо попираемых варварами? Ведь не приставят же к каждому сайту контролера? А общие действия союзов государств могут предотвратить деградацию населения в заданном агрессором (кто бы он ни был!) направлении триангуляции.

Но что может являться основанием новой, более общественной триангуляции?

Если рассмотреть каждую страну, как своеобразную социальную машину, выкованную тысячелетиями взаимной обработки, то речь может пойти о специальной деятельности по гармонизации во всемирном масштабе взаимоотношений между всеми странами, о разработке и непрерывной коррекции нормативной системы, обеспечивающей наиболее гладкие взаимоотношения между разными частями общего человечества. Т.е., направление триангуляции резко меняется на противоположное: сопрягать страны не наиболее враждебным образом, а наиболее компромиссным!

Неожиданно в наших рассуждениях начинает возникать роль мудрости не только как человеческого опыта, общей для всех народов сокровищницы, но как инструмента создания нового мирового порядка. Мудрость выше науки, равно как и выше философии. Ибо наука характеризуется повторяемостью результата (вскрывает закономерности), тогда как мудрость всегда уникальна, сообразна обстоятельствам и выступает уделом жизненного опыта, бессознательного наития (чутья) или даже «божественного откровения».

Правила научного познания требуют, чтобы низшее познавалось в свете высшего. Мудрое поведение есть наивысший тип социального поведения, это правильное поведение в данных 
условиях, в отличие от множества фактически реализуемых и часто неправильных действий, совершаемых не мудрыми людьми. Тогда появляется некий канон, норма, с которой можно сравнивать тысячи разнообразных действий и подвергать их оценке или коррекции. Мудрость считается высшей, идеальной точкой человеческого развития. По одному из определений, мудрость есть способность находить оптимальное решение сложных жизненных проблем, опираясь на свой и чужой опыт и знания. В отличие от философии, мудрость - нечто большее, чем интеллектуальная развитость, обладание обширным знанием, понятийное жонглирование или же компетентность эксперта. Это способность ставить любое знание в связь с общим смыслом бытия, с достоинством, призванием и назначением человека, с духовно-нравственными основами его мысли и жизни; это также искусство жить согласно обретенному смыслу. Мудрость, в отличие от философии, выходит за понятийные конструкции, дает практические советы и сама следует им. Мудрость - это не просто знание истины, но и воплощение истины.

Считается, что мудрости выучиваются, практикуя ее. Если невозможно практиковать мудрость, то нельзя и научиться ей. Если же не учиться ей, то в действительности, мудрость и не появится. Мудрость выправляет беды, несчастья и устраняет трагедии.

Мудрость нужна особенно сегодня, когда мы находимся в определённом моменте эволюционного кризиса в истории человеческого рода, когда наработанные образцы поведения дают сбой. Нам нужна креативность и своего рода творчество, чтобы освободиться от опасностей и препятствий, которые человек создал в прошлом.

Человечество должно сейчас придумать какие-то способы, которые помогли бы отойти от разрушительных для планеты ситуаций. Если мы не будем мудрыми людьми, то мы некоторым образом будем уничтожены злокачественными нарывами прошлого.

Мудрость и политика

Позиция государства в иерархической системе международных отношений, его сила и мощь, развитость или отсталость, система ценностей и военно-политическая ориентация весьма динамичны в современном мире. Нужно учитывать, что завтра в государстве могут смениться все лозунги, и герои станут преступниками, и наоборот. Тогда любое решение будет оптимальным только на период стабильности. Если же большинство решений отличается мудростью, то они неколебимо оптимальны в любых условиях. Все остальные страны оказываются в «догоняющей» позиции.

Мудрость, которая расшифровывает все стратагемы врага, это мудрость полководца, одерживающего очередное сражение над врагом, и, не глумясь над поверженным соперником, великодушно подает ему руку. Победитель как бы говорит, я всегда смогу тебя победить, но я не хочу войны. Я предлагаю тебе мирное сотрудничество, но в рамках этих правил. Если ты выйдешь за их пределы, то ты будешь наказан. Исключительна в этом плане история о китайском полководце, который 7 раз побеждал врага, но отпускал его, пока тот не смирился и не стал другом. Мудрость сама не предпринимает уловок, но видит прозрачно все козни врага, понимая, что тот пожнет, что посеял.

Послушаем одну китайскую историю.

В 971 году князь Лю из южных Ханей капитулировал после многих лет бунтов и восстаний. К изумлению Лю, император Сун предоставил ему должность при императорском дворе и пригласил во дворец, чтобы скрепить вином новый дружеский союз. Принимая чашу, предложенную ему императором Суном, Лю коле- 
бался, опасаясь, что в вине окажется яд. Он простонал:

Ваш раб безусловно заслуживает смерти за свои преступления, и все же я умоляю Ваше Величество о даровании жизни. Видите, я не решаюсь выпить это вино.

Император Сун рассмеялся и сам выпил вино, взяв из рук Лю чашу. Яда в ней не было. С той поры Лю стал его самым верным и преданным другом.

Вместо того, чтобы опираться на друзей, император Сун превращал врагов и противников В самых надежных союзников. В то время, как охваченный ревностью друг ожидает новых и новых милостей, эти бывшие неприятели не ждали ничего, а получили все. Человек, избежавший гильотины, на самом деле испытывает благодарность и пойдет на край света ради своего избавителя. Со временем прежние враги стали для императора верными друзьями.

Удивительное сходство этого мудрого решения с христианским принципом «Возлю-

\section{ЦИТИРОВАННАЯ И УПОМЯНУТАЯ ЛИТЕРАТУРА}

1. Армянский центр стратегических и национальных исследований: geum.ru бите врагов ваших!», показывает коренящийся в этих правилах рационализм и универсальное значение мудрости для всех культур и цивилизаций.

Сегодня наша последняя надежда на мудрость. Она должна подсказать нам, с чем примириться, а с чем бороться до последнего вздоха. Мудрость становится источником новых технологий, новых обучающих методик общения с народами, против их деградации. Даже малые и слабые народы, осваивая эти методики и готовя прошедшие это обучение кадры, смогут умело воздействовать на процессы триангуляции, сдвигая мировой порядок к общеприемлемым, наиболее гармоничным конфигурациям. При этом экспансия из негативного становится позитивным качеством, становится экспансией добра, позитивности, созидательности, справедливости, гуманизма, наконец.

2. Вольфганг, Г. (2005) Геноцид армян. Инстиmут истории. Ереван, изд-во: НАН РА, Айастан (Гракан айреник).

3. Уткин, А. ( 2000) Забытая трагедия. Россия в первой мировой войне. Смоленск : http://wordweb.ru/wwone/10.htm.

ГРИГОРЬЯН ЭРНЕСТ

\section{МУДРОСТЬ КАК ИНСТРУМЕНТ СОЗДАНИЯ НОВОГО МИРОВОГО ПОРЯДКА}

\section{PEЗЮME}

В статье рассматривается нынешнее состояние мирового порядка в его социальных аспектах, обосновывается доминирование в мире частных кланов и частных интересов в ущерб общественному бытию человечества, утверждается аномальность такого состояния, показывается возможный выход из него с опорой на игнорируемое сегодня в политике понятие муд- 
рости. В качестве средств разрешения назревших противоречий предлагается усилить гуманитарную работу с населением находящихся в кризисе стран. Для этого на факультетах социологии готовятся специалисты-миротворцы, владеющие методиками управления массовым поведением, гашения конфликтов, умиротворения враждующих сторон, создания социальных уз и связей в анти-либеральном формате, в духе традиционных ценностей.

Ключевые понятия: мировой порядок, триангуляция, геополитическая конфигурация, клан, мудрость, управление, гуманизм.

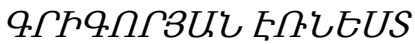

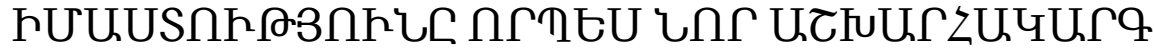

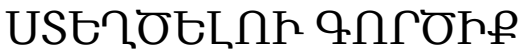

\section{UUФПФПЋU}

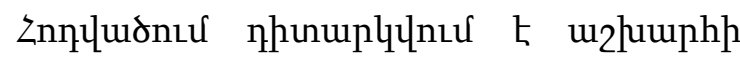

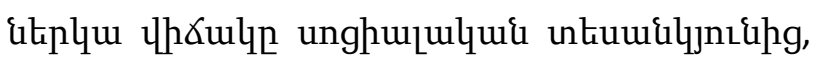

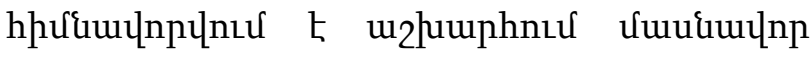

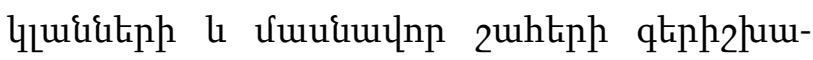

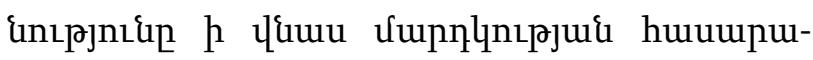

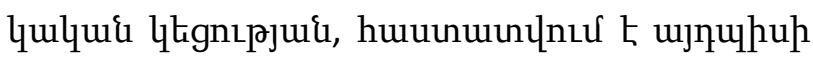

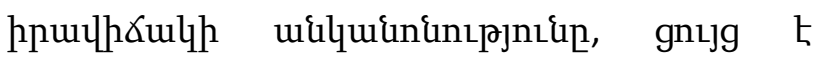

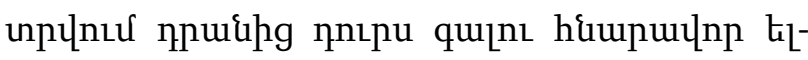
ptipn' htilltinnl ujuop punupulquinıpjui

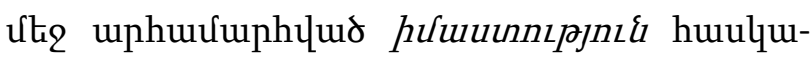
gnıpjuí цpu: กpultu huunsquagur hulquunıpjnı\&ukph humpuhupưue uheng' unu-

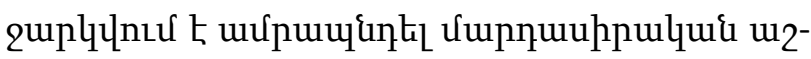

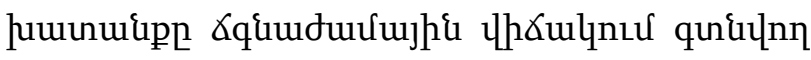
Łplpukph paulınıpjui htin:

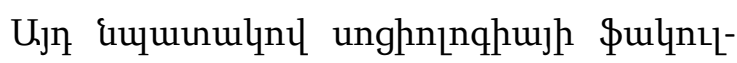

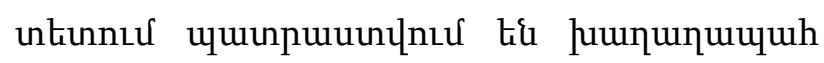

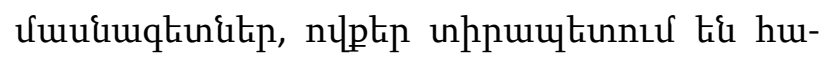
umpulqulues lupph qunurupruid, hulqu-

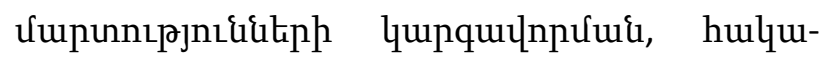

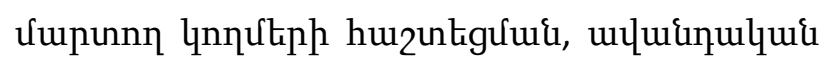
updtpitiph nqnц humunulqulume quultph

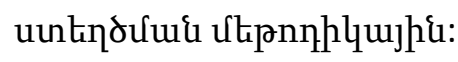

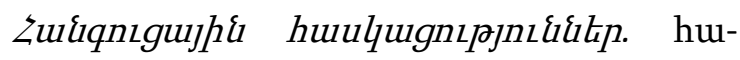

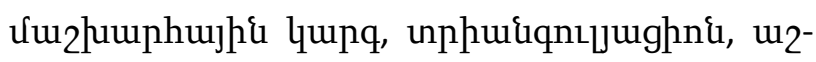

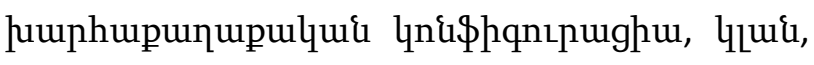

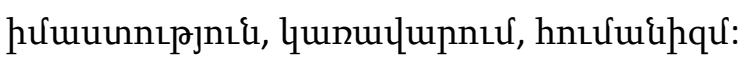




\section{WISDOM AS TOOL FOR CREATION OF NEW WORLD ORDER}

\section{SUMMARY}

The article discusses the current state of the world order in its social aspects, justified dominance in the world of private clans and their private interests to the detriment of social being of humanity, criticizes the anomaly of this state, shows the possibility of building the new world order on Ignored in politics today the concept of wisdom. As a means of resolving conflicts is proposed to strengthen the urgent humanitarian work with the population being in crisis countries. To do this, necessary in the departments of sociology prepare specialists-peacekeepers owning management practices of mass behavior, suppression of conflict, peace warring parties, creating social ties and connections in the anti-liberal format, in the spirit of traditional values.

Key concepts: world order, triangulation, geopolitical configuration, clan, wisdom, control, humanism. 